小腸平滑筋肉腫の 3 切除例と本邦文献報告例224例の検討

\begin{tabular}{|c|c|c|c|}
\hline & & 三重大学第 1 外和 & \\
\hline & 貴行 & 小坂 & 東 \\
\hline 野口 & 孝 & 川原田嘉文 & 水本 \\
\hline
\end{tabular}

\title{
TREE CACES OF LEIOMYOSARCOMA OF THE SMALL INTESTINE WITH REVIEW ON 224 CACES OF LEIMYOSARCOMA OF THE SMALL INTESTINE IN JAPAN
}

\author{
Takayuki NAKAHAMA, Atsushi KOSAKA, Shunsaku HIGASHI, \\ Takashi NOGUCHI, Yoshifumi KAWARADA and Ryuji MIZUMOTO
}

1st Department of Surgery, Mic University School of Medicine

索引用語：小腸癌, 小腸平滑筋肉腫

\section{はじめに}

小腸原発の平滑筋肉腫は比較的まれな疾患である が，近年，消化管画像検查の進歩に伴いその報告例も 増加している。最近 10 年 2 カ月間に教室では小腸（十 二指腸を除く) 平滑笳肉腫 3 例を経験しいずれも切除 しているので報告するとともに，最近 15 年間の本邦文 献から小腸平滑筋肉腫224例と小腸癌275例を集計し, 両者の臨床的特徵を比較検討して報告する。

\section{症 例}

症例 $1: 62$ 歳, 女性.

主訴：腹痛と腹部腫瘤.

家族歷，既往歴：特記すべきことなし。

現病歴：1981年 6 月ごろより腹痛が出現し，腹部腫 瘤を触知したため本院婦人科に入院.

婦人科入院時理学的所見：負血，黄疸なく，腹部で は脐左側下万弾性硬で可動性を有する手拳大の腫瘤 を触知した。

検查成績：血液括よび生化学的検查成續はいずれも 正常で，腹部単純撮影でも異常なかったが，超音波検 查やCT は施行されなかった，入院 2 日後に突然腹痛 が増強し, 卵巣賈腫茎捻転の疑いで婦人科で手術が施 行された。

手術所見：卵巣には異常はなかったが，Treitz 勒帯 より $30 \mathrm{~cm}$ 肛門側空腸に壁外性に発育した手拳大の腫 瘍を認めたため当科が引きつぎ手術を施行，所属りン

$<1987$ 年 6 月 8 日受理 $>$ 別刷請求先 : 中浜 貴行 T514 津市江戸橋 $2-174$ 三重大学医学部第 1 外科
図 1 症例 1，62歳，女性：空腸庫場の切除標本。

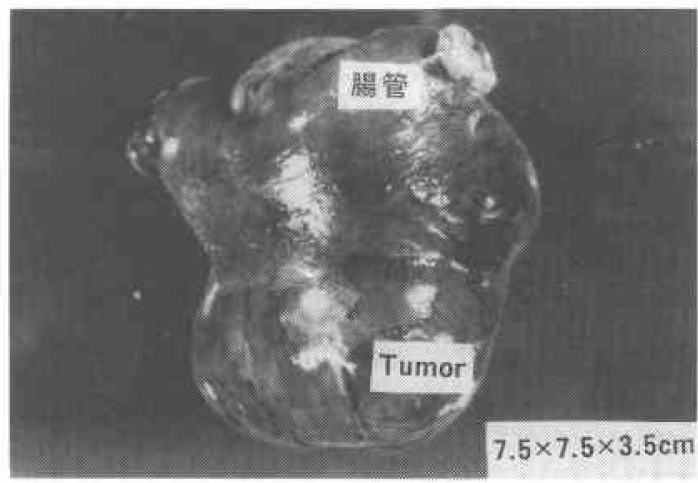

パ節を含めて腫瘍より口側並びに肛門側とれぞれ10 $\mathrm{cm}$ の部位で空腸を切離し, 端々吻合にて再建した。

切除標本：腫湯は空腸壁より腸間膜側へ壁外性に発 育し，大きさ $7.5 \times 7.5 \times 3.5 \mathrm{~cm}$ で，割面では中心壊死 を伴っていた（図1).

組織学的所見：腫瘍は核異型の強い大型の核を持つ 紡鍾形細胞からなり，一部に核分裂像 (10視野に 7 個) を認め平滑筋肉腫と診断された。リンパ節転移は認め られなかった。

術後経過は良好で, 術後14日目より Endoxan 100 $\mathrm{mg} /$ 日の経口投与を行い， 5 年 5 カ月の現在再発の兆 候なく健在である。

症例 $2: 73$ 歳, 男性.

主訴：下腹部膨満感。

既往歴：心筋梗塞（入院 7 年前). 
現病歴：1984年12月ごろより下腹部膨満感あり某医 を受診、下腹部に小児頭大の腫瘤を指摘され1985年 3 月14日当科酒入院.

入院時理学的所見：負血, 黄疸なく, 腹部は下腹部 が膨満し，脐下に弾性硬で小児頭大の表面凸凹不整で わずかに可動性を有する畽瘤を触知した。

検査成績：血液打よび生化学的検查に異常なく, 腫 場マーカーも正常であったが，心拍出量 $3.4 \mathrm{l} / \mathrm{min}$ ，心 係数 $2.4 \mathrm{l} / \mathrm{min} / \mathrm{m}^{2}$ と心機能の低下が認められた。腹部 画像検查についてみると, US 拉よびCT では内部に 中心壊死を伴った巨大な腫瘍を認め，上腸間膜動脈造 影にて回結腸動脈末梢に腫瘍血管を認めたが，膀腃拉 よび尿管は圧排所見のみであった（図 2)，以上より回 腸原発の悪性腫瘍と診断し手術を施行した.

手術所見：回盲弁より $50 \mathrm{~cm}$ 口側回腸上り壁外性に 発育した小児頭大の腫瘍を認めたが，肝転移や周囲と の瘉着はなく，所属りンパ節を含めて腫瘍より口側, 肛門側それぞれに $10 \mathrm{~cm}$ の部で回腸を切離し，端々吻 合にて再建した。

切除標本：腫瘍は回腸壁より腸間膜対側へ壁外性に 発育し，大きさ $16.5 \times 10 \times 7 \mathrm{~cm}$ で，割面では中心壊死 を伴っていた（図3）.

組織学的所見：腫瘍は異型の強い核を持つ紡錘形細 胞が密に不規則に交錯し，核分裂も10視野に15個認め られ平滑筋肉腫と診断された。リンパ節転移は認めら れなかった。

術後経過は良好で, Adriamycin 10mg, 8 回計 $80 \mathrm{mg}$ 静注し, 1 年 8 カ月の現在再発の兆はない.

症例 $3: 61$ 歳, 男性.

図 2 症例 2 , 72歳, 男性: 下腹部腫瘤の CT 像. 小 児頭大の巨大な腫瘤を認め中心壊死を伴っている。

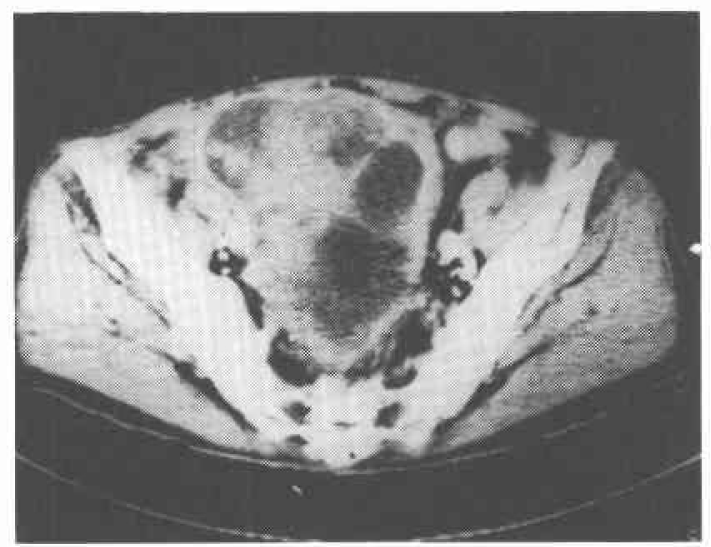

主訴：吐下血。

家族歴，既往歴：特記すべきことなし．

現病歷：入院 2 日前より突然吐下血をきたしショッ ク状態となり某病院に入院. 胃内視鏡検査にて出血点 が確認されず，精査の目的で当科へ入院した。

入院時理学的所見：貧血著明で血圧は $80 / 50 \mathrm{mmHg}$ と低下し，腹部は軽度膨満するる腫瘤を触知しなかっ た.

検查成績：血液検査で赤血球数 $244 \times 10^{4} \mathrm{~mm}^{3}, \mathrm{Hct}$ $22.1 \%$ 著明な貧血を認め, BUN $49 \mathrm{mg} / \mathrm{dl}$, creatinine $1.5 \mathrm{mg} / \mathrm{dl}$ と上昇していたが，肝機能扔よ び腫場マーカーには異常は認めなかった。一方, 腹部 画像検查についてみると，腹部血管撮影で，空腸動脈 第 1 枝末梢に $3 \times 3 \mathrm{~cm}$ 大の腫瘍濃染像と内部血管の不

\section{図 3 症例 2 の切除標本}

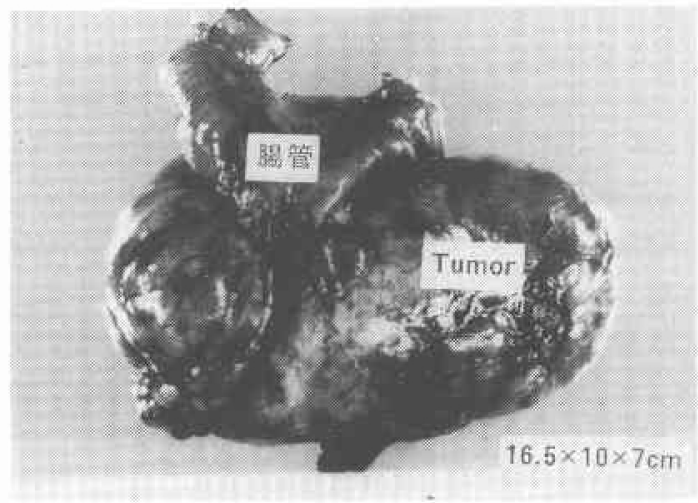

図 4 症例 3.61歳, 男性：消化管出血, 上腸間膜動 脈造影。著明な腫瘍濃染像を認める。

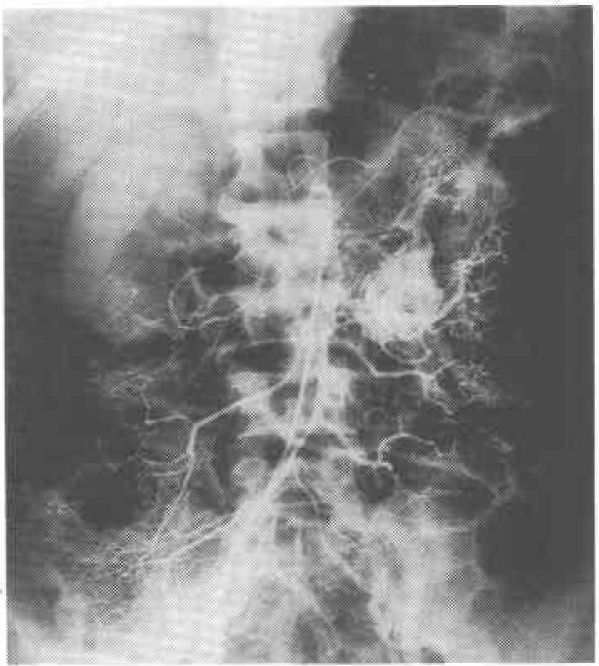


図 5 症例 3 の切除標本. 粘膜面に Ul-IV の潰瘍を認 める(矢印).

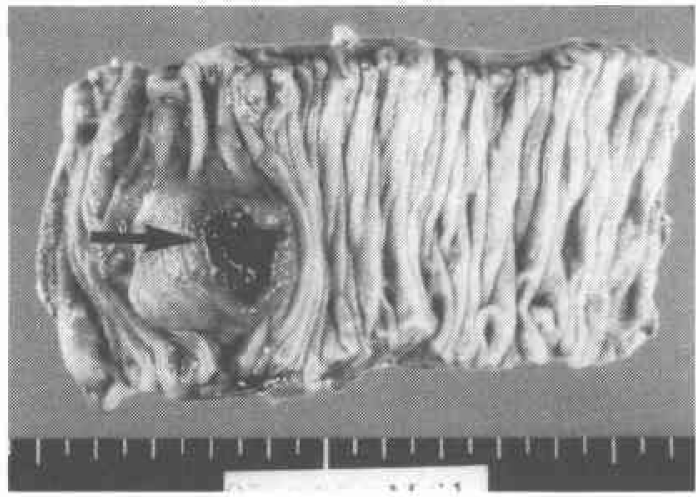

整が認められた（図４）．以上より小腸腫瘍からの出血 と診断し緊急手術施行。

手術所見：Treit $z$ 靯带より $20 \mathrm{~cm}$ 肛門側空腸に壁外 性に発青した鶏卵大，弾性硬の腫瘍を認め，所属リン パ節を含めて口側，肛門側それぞれに $5 \mathrm{~cm}, 10 \mathrm{~cm} の$ 部 で空腸を切離し，端々吻合にて再建した。

切除標本：腫瘍は，空腸壁より腸間膜対側入壁外性 に発育し,大きさ $3 \times 3 \times 2 \mathrm{~cm}$, 空腸粘膜面には Ul-IV の 潰瘍を形成していた（図 5 ).

組織学的所見：腫瘍は，核の大小不同之異型性のあ る紡錘形細胞からなり，核分裂像は10視野に 8 個であ り平滑筋肉腫と診断された。

術後経過は良好で, 術後14日目より Endoxan 10 $\mathrm{mg} /$ 日の経口投与を行い, 1 年 4 カ月の現在健在であ る.

\section{考察}

1. 原発性小腸平滑筋肉腫の頻度：小腸平滑筋肉腫 の頻度は全消化管悪性腫瘍中 $0.11 \sim 3.1 \%{ }^{12)}$ と言われ ているが，教室で最近10年 2 力月間(1976，9 - 1986 . 11）に経験した消化管悪性腫湯606例中，小腸平滑筋肉

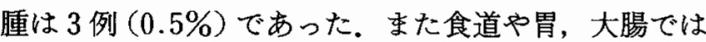
王倒的に癌腫が多かったのに対し，小腸では悪性腫瘍 5 例中癌腫 2 例 $(40 \%)$ 平滑筋肉腫 3 例 $(60 \%)$ と平 滑筋肉腫が多かった。

八尾ら゙)の集計した本邦における小腸悪性腫瘍482 例中，癌腫が178例，平滑筋肉腫は64例，その他 240 例 と癌腫が多く，James $5^{4)}$ が過去40年間の欧米文献か ら集計した小腸悪性腫瘍2,144例中でも癌腫 1,002 例, 平滑筋肉腫421例，その他721例之癌腫が多かった。

2. 原発性小腸平滑筋肉腫本邦文献報告例の検討, 特
図 6 小腸癌と小腸平滑筋肉腫の年龄と男女比一本邦 文献報告例の比較検討一(1971 1985)
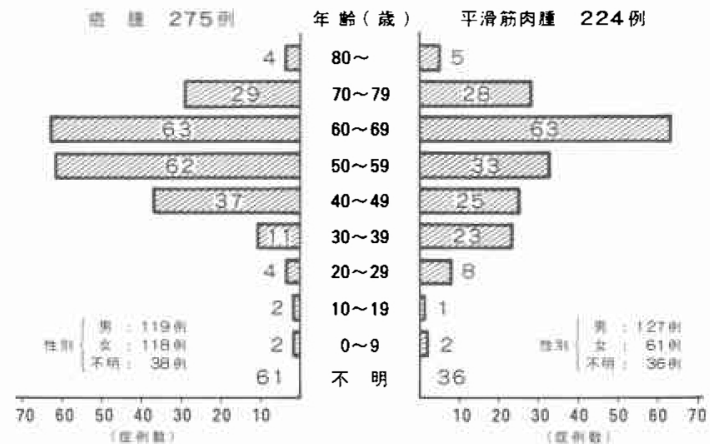

図 7 小腸癌と小腸平滑筋肉腫の主症状一本邦文献報 告例の比較検討一 $(1971 \sim 1985)$

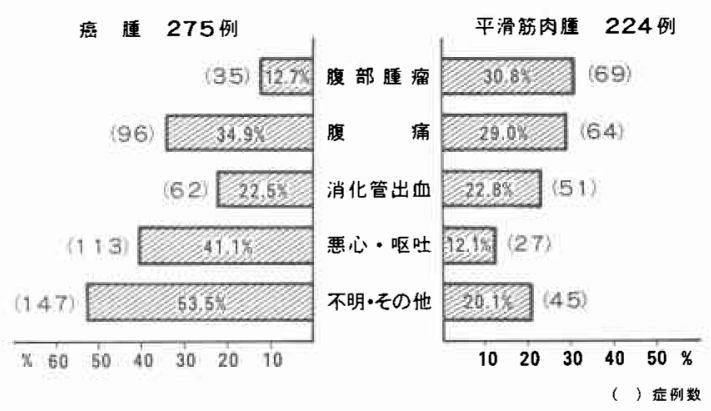

に小腸癌との対比：われわれは1971年〜1985年末まで の15年間に本邦で報告された小腸平滑筋肉腫224例と 同期間に報告された小腸癌275例とを対比し，それぞれ の臨床的特徴について検討した.

1）年齢, 性差：小腸平滑筋肉腫の年齢は60歳台に最 も多く, 性別では男性127例, 女性61例と男性が多かっ た。一方，小腸癌は50歳台和よび 60 歳台が最も多く， 男性119例，女性118例であり性差を認めなかった（図 6 ).

2）主症状：小腸平滑筋肉腫では腹部腫瘤が69例 (30.8\%) と最も多く，ついで腹痛64例 (29.0\%)，消 化管出血51例 $(22.8 \%)$ ，悪心呕吐が27例 (12.1\%) て あったのに対し，小腸癌では腹部腫瘤は35例(12.7\%) と少なく，悪心呕吐が113例 (41.1\%) と最も多く，腹 痛は96例 $(34.9 \%)$ と平滑筋肉腫よりやや高率であっ たが，消化管出血は62例 $(22.5 \%)$ で平滑筋肉腫と大 差なかった。これらの主症状は，平滑笳肉腫では腫瘍 増大による症状が主体をなして扔り，小腸癌では閉塞 や狭窄による症状が特徵的と考えられた（図 7)。 
図 8 小腸癌之小腸平滑筋肉腫の発生部位一本邦文献 報告例の比較検討一（記載の明らかな症例のみ） (1971 1985)

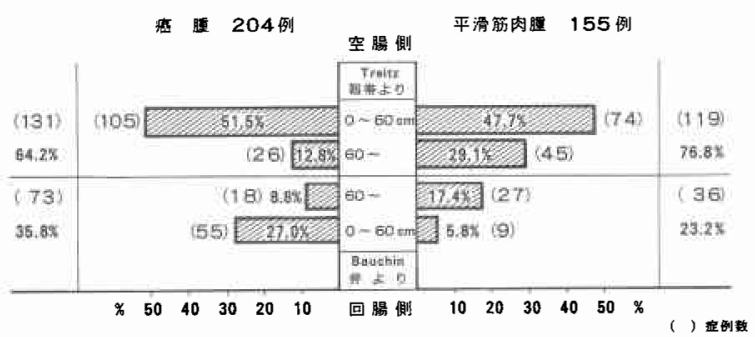

3）腫瘍発生部位：小腸平滑施肉腫では，空腸側119 例 $(76.8 \%)$, 回腸側 36 例 $(23.2 \%)$ ，小腸癌では，空 腸側131例 (64.2\%)，回腸側73例（35.8\%）とともに 空腸側に多かった。さらに、これらを空腸はTreitz 靯 帯, 回腸では Bauhin 弁からの距離で比較してみると, 平滑筋肉腫では Treitz 靯帯より $60 \mathrm{~cm}$ 以内に 74 例 $(47.7 \%)$ とその半数近くが口側空腸にみられ以後肚門 側に向らに従って减少し Bauhin弁より $60 \mathrm{~cm}$ 以内の 回腸が 9 例 $(5.8 \%)$ と最す少なかった。一方，小腸癌 では，Treitz 勒带より $60 \mathrm{~cm}$ 以内に105例 (51.5\%) と 半数以上が口側空腸に認められたのは平滑筋肉腫と同 様であったが，ついで平滑筋肉腫では最す少なかった Bauhin 弁より $60 \mathrm{~cm}$ 以内が55例 $(27.0 \%)$ と多く，そ れより口側回腸が最も少なく小腸平滑筋肉腫と比較し て特徵的と考光られた（図 8).

4）予後：小腸に拈ける平滑筋肉腫および癌腫の 5 年生存率は諸家によりそれぞれ30\%，25\%5或は44\%，

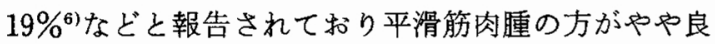
好である. Patrick ら 期間が 1 年以上, (2)リンパ節或は遠隔転移のないもの, (3)腫啺径が $9 \mathrm{~cm}$ 以下のものでは明らかに予後は良好 で、これらすべてを满たした症例では 5 年生存率が 89\%ときわめて良好であると報告している，さらに組 織学的に核分裂像の頻度も予後と関係が深く, 10 視野 （400倍）に10個以上認めるものは予後不良といわれて いる8). な Awrich ら9)は小腸の平滑筋肉腫および癌 腫の 5 年生存率はそれぞれ $37.5 \% ， 26 \%$ あるが，リ ンパ節郭清などを含めた根治術を施行することにより
それぞれ $50 \%$ の 5 年生存率を得ることができ，さらに AdriamycinやEndoxan などの化学療法を併施すれ ば予後は一層向上すると述べており，われわれも症例 1，3に Endoxan, 症例 2 には Adriamycin を投与し 良好な結果を得ている。したがって小腸平滑筋肉腫に 対しては，早期に発見し，積極的に切除するだけでな く, 術後化学療法を併施することにより予後の改善が 期待できるものと考党られた。

\section{結語}

最近 10 年 2 力月間にわれわれは 3 例の小腸平滑筋肉 腫を経験したので報告した。いずれも所属りンパ節を 含めて切除した後, 化学療法を併施して術後 1 年 4 力 月 5 年 5 力月の現在健在である.さらに最近 15 年間 に本邦で報告された小腸平滑筋肉腫224例および小腸 癌275例を集計し, 両者の臨床像や治療法ならびに予後 などについて比較検討し，あわせて報告した。

$$
\text { 文献 }
$$

1）川井啓市, 馬場忠雄, 赤坂裕三潘か：わが国に扑け る小腸疾患の現況之展望. 胃之腸 $11 ： 145-155$, 1976

2）中神一人，二村雄二，弥政洋太郎：小腸悪性腫場の 臨床像。消外 $6: 25-32,1983$

3）八尾恒良, 日吉雄一，田中啓二ほか：最近 10 年間 （1970－1979）の本邦報告例の集計からみた空回腸 腫煌。胃と腸 $16 ： 935-941 ， 1981$

4) James MW, David BM, George FG et al: Primary malignancies of the small bowel. Ann Surg 180: 175-179, 1974

5) Terry AT, Raleigh RW : Primary tumors of the small bowel. Am J Surg $130: 749-755,1981$

6）沢田俊夫, 武藤徹一郎, 草間 悟：原発性小腸腫 瘍. 消外 4:499-505, 1981

7) Patrick JP, Victor WF : Prognostic factors of 28 leiomyosarcomas of the small intestine. Surg Gynecol Obstet $155: 197-202,1982$

8）高木国夫，山本英昭：胃腸管平滑筋肉腫一50例の 臨床的特徵について一. 消外 5:1507-1513, 1981

9) Awrich $\mathrm{AE}$, Irish $\mathrm{CE}$, Vetto $\mathrm{RM}$ et al: A twenty" ve year experience with primary malig. nant tumors of the small intestine. Surg Gynecol Obstet $151: 9-14,1980$ 